NBER WORKING PAPER SERIES

\title{
WHO DIES? INTERNATIONAL TRADE, MARKET STRUCTURE, AND INDUSTRIAL RESTRUCTURING
}

\author{
Andrew B. Bernard \\ J. Bradford Jensen
}

Working Paper 8327

http://www.nber.org/papers/w8327

\author{
NATIONAL BUREAU OF ECONOMIC RESEARCH \\ 1050 Massachusetts Avenue \\ Cambridge, MA 02138 \\ June 2001
}

\begin{abstract}
We thank Jim Harrigan for providing the country endowment data. We thank Peter Schott and seminar participants at the NBER, Wisconsin, Oregon and UBC for many helpful comments. The data used are confidential but not exclusive. The research was conducted at the Center for Economic Studies. Research results and conclusions expressed are those of the authors and are not those of the National Bureau of Economic Research nor do they necessarily indicate concurrence by the Bureau of the Census. The paper has not undergone the review the Census Bureau gives its official publications. It has been screened to insure that no confidential data are revealed. The views expressed herein are those of the author and not necessarily those of the National Bureau of Economic Research.
\end{abstract}

(C) 2001 by Andrew B. Bernard and J. Bradford Jensen. All rights reserved. Short sections of text, not to exceed two paragraphs, may be quoted without explicit permission provided that full credit, including $\odot$ notice, is given to the source. 
Who Dies? International Trade, Market Structure, and Industrial Restructuring Andrew B. Bernard and J. Bradford Jensen

NBER Working Paper No. 8327

June 2001

JEL No. F11, L16, L60

\section{$\underline{\text { ABSTRACT }}$}

This paper examines the role of changing factor endowments in the growth and decline of industries and regions. The implications of an endowment-based Heckscher-Ohlin trade model for plant entry and exit are tested on 20 years of data for the entire US manufacturing sector. The trade model provides predictions for which industries will see growth through the positive net entry of plants. A multiregion version of the same model has predictions for which regions will see high turnover and net entry of plants. In a country such as the U.S. that is augmenting both its physical and human capital, the least capital-intensive, least skill-intensive industries are correctly predicted to have the lowest rate of net entry. In addition, increases in regional capital and skill intensity are associated with higher probabilities of shutdown, especially for plants in industries with low initial capital and skill intensities.

Andrew B. Bernard

Tuck School of Business

Dartmouth College

100 Tuck Hall

Hanover, NH 03755

and NBER

Tel: 603-646-0302

Fax: 603-646-0995

andrew.b.bernard@dartmouth.edu
J. Bradford Jensen

Center for Economic Studies, Bureau of the Census

University of Maryland 
Who Dies? International Trade, Market Structure, and Industrial Restructuring 2

\author{
Plant Shutdown Will take out 275 JobS \\ 08/18/1999 Associated Press Newswires \\ VAN WERT, Ohio (AP) - One of the county's largest \\ employers is closing despite an offer of $\$ 15$ million \\ in government assistance. \\ Belgium To Sue Renault Over Planned Plant \\ Closure \\ 03/03/1997 Dow Jones News Service
}

\title{
1. Introduction
}

Closures of manufacturing plants are big news. Local communities and plant workers mobilize to protest the closures, while local politicians often offer financial carrots and sticks to keep the plants open. ${ }^{1}$ Increasingly in recent years, headlines accompanying plant closure notices have cited international forces as the reasons behind the shutdowns. In this paper, we develop and test the predictions of an endowment-based trade model for rates of plant entry and exit across industries and regions. Of particular interest are the predictions of the model for the interaction between changes in regional factors and industrial restructuring.

This paper examines the shutdown of manufacturing plants across industries and regions. We develop the implications of endowmentbased Heckscher-Ohlin trade models for plant entry and exit and augment them with insights from the market structure models of endogenous plant heterogeneity such as Hopenhayn (1992a). HeckscherOhlin models have predictions for net entry rates across industries and regions. In contrast, the market structure models concentrate on explaining the comovement of entry and exit rates across industries and have no predictions for net entry or regional variation. We consider both variation across industries and variation across regions in

\footnotetext{
${ }^{1}$ In contrast, the closure of service sector establishments rarely merits front page headlines.
} 
Who Dies? International Trade, Market Structure, and Industrial Restructuring 3

our empirical work.

Heckscher-Ohlin trade models provide predictions both for which industries will grow (positive net entry rates) and for which regions will see high turnover and net entry of plants. ${ }^{2}$ In a country augmenting both its physical and human capital such as the US, the least capitalintensive, least skill-intensive industries are correctly predicted to have the highest exit rates. In addition, we develop a new component of the plant-level data and exploit the geographic detail available by dividing the US into individual labor market regions. ${ }^{3}$ As predicted by the Heckscher-Ohlin model, regions within the country that have the biggest endowment changes are associated with higher exit rates and higher entry rates. For regions accumulating capital, the endowmentbased trade model correctly predicts that net entry rates are higher for capital-intensive industries.

Because of their inherent focus on steady state equilibria, the market structure models cannot predict variation in net entry rates. Existing market structure models do, however, correctly predict that entry and exit rates will covary positively across industries. High entry costs cause both low entry and low exit probabilities. The entry cost proxies that correctly predict the comovement in industry entry and exit rates explain none of the heterogeneity in net entry rates across industries.

This work at the industry and regional levels confirms the importance of the market structure models in explaining industry level comovements in plant entry and exit rates. More importantly, we introduce endowment-based trade theory as an important additional component of the ongoing evolution of the US manufacturing sector. While the market structure models had little role for net entry, a simple $\mathrm{H}-\mathrm{O}$ trade model does well in not only predicting which industries

\footnotetext{
${ }^{2}$ Of course, the Heckscher-Ohlin model is silent on the sources of covariation in entry and exit.

${ }^{3}$ In this paper, we do not take a stand on whether plants in these regions face the same factor prices. The regional predictions developed below hold if the US regions are in either a single or multiple factor price equalization cones.
} 


\section{Who Dies? International Trade, Market Structure, and Industrial Restructuring 4}

should see net entry but also where those capital-intensive industries will locate.

The rest of the paper proceeds as follows: Section 2 details the predictions for industry and regional entry, exit and net entry from a simple Heckscher-Ohlin trade model and the market structure models. The description of the data, the basic empirical specification, and main results follow in Section 3. Conclusions are presented in Section 4.

\section{Predictions from the models}

In this section we develop a set of testable hypotheses from a basic Heckscher-Ohlin model of trade about entry and exit for both industries and regions. We also examine the empirical predictions of existing industry models of plant exit and entry.

While the effects of international trade on domestic economies are the subject of heated debate, surprisingly little is known about the actual mechanisms by which trade affects the economy. Trade theory offers predictions about the evolution of industries and economies over the long run, but is usually silent on the means by which the transformations occur. Heckscher-Ohlin trade models, for example, predict changes in industry composition as a result of changing endowments within a country. In a country such as the US which has been increasing both its physical and human capital intensity as shown in Figure 1 , these models predict that the mix of industries will change towards more capital intensive products. ${ }^{4}$ Hanson and Slaughter (1999) report such a shift of product mix in US states in response to increased immigration during the 1980s. ${ }^{5}$ The models themselves usually do not predict how these changes will show up in the economy. One

\footnotetext{
${ }^{4}$ The data underlying Figure 1 come from Harrigan and Zakrajsek (2000). Skilled labor is measured as the workforce with some secondary education. If we were interested in the factor content of trade we would want to look at the US endowment changes relative to the rest of the world.

${ }^{5}$ Schott (1999) provides evidence on the cross-sectional variation in goods produced by countries with different capital-labor ratios.
} 
Who Dies? International Trade, Market Structure, and Industrial Restructuring 5

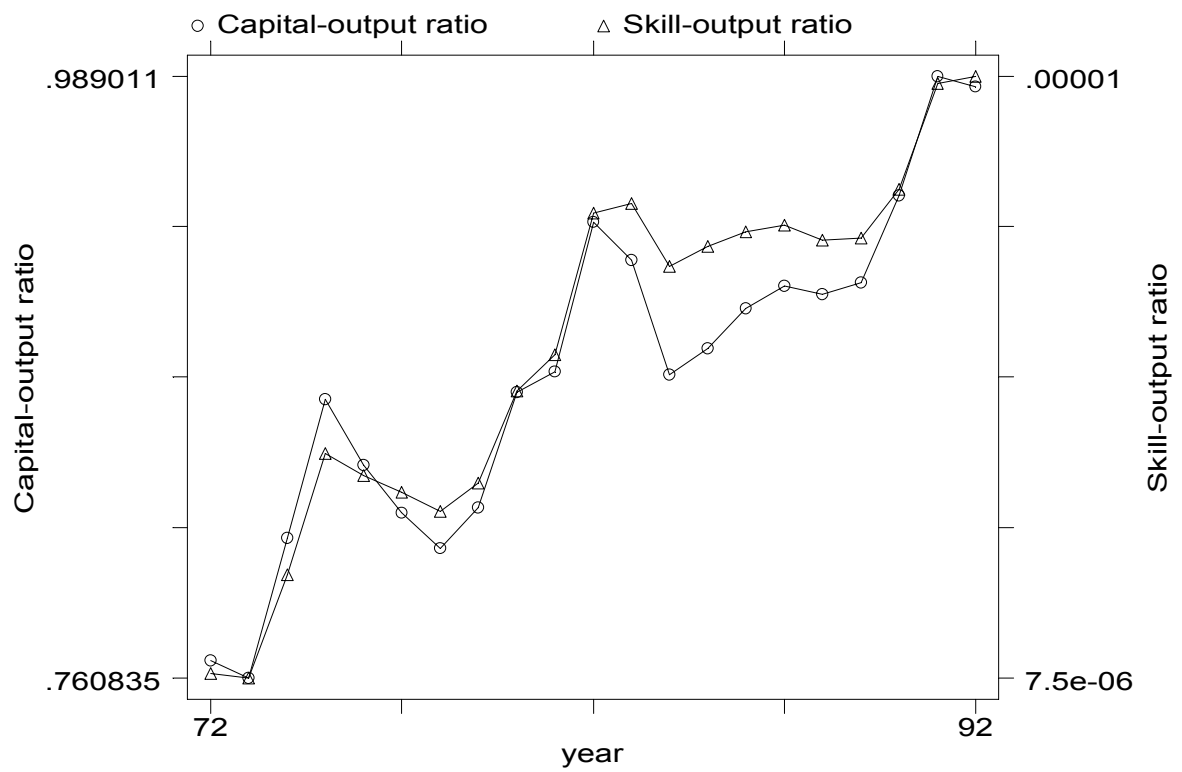

Figure 1: Increases in Capital and Skill Intensity in the US, 1972-1992

possibility is for industries to adjust the mix of products entirely at existing plants, changing the factor intensities and/or product mix at those facilities. At the other extreme, the adjustment comes entirely through exits and entrants as outdated plants are shuttered and new facilities are opened. ${ }^{6}$

In this paper we focus on one possible adjustment margin, the decision to shut down manufacturing facilities and by implication the decision to open new plants. In any five year period, more than 35 percent of existing US manufacturing plants are closed. ${ }^{7}$ Typically,

\footnotetext{
${ }^{6}$ In April, 2001, the Chrysler unit of DaimlerChrysler opened a $\$ 700$ million Jeep Liberty factory heavily dependent on robots. At the same time Chrysler announced that it would greatly increase production of the hot-selling Chrysler PT Cruiser by expanding a factory in Mexico instead of using one in Illinois.

${ }^{7}$ The large number of shutdowns is substantially offset by the large number of new establishments created over a five year period. See Dunne, Roberts, and
} 
Who Dies? International Trade, Market Structure, and Industrial Restructuring 6

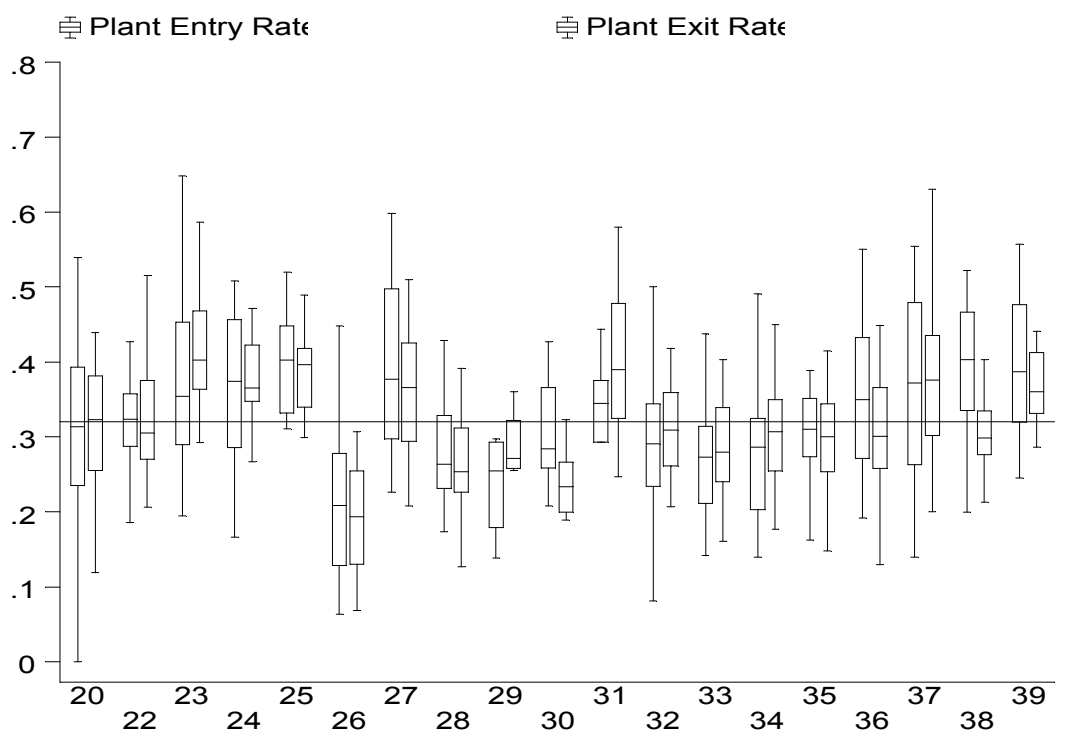

Figure 2: Entry and Exit Rates, 4-Digit (SIC) Industries, 1987-1992

smaller establishments are the most likely to exit, but closures are relatively frequent events even for the large facilities that garner so much news coverage. Of plants with more than 250 employees, over 16 percent will close in any five year interval accounting for 7.8 percent of manufacturing employment.

Unlike previous work on plant shutdown and startup, our focus is primarily on net entry of plants, or changes in industrial structure. Existing dynamic industry models are based primarily on the empirical findings of Dunne, Roberts and Samuelson $(1988,1989)$ that plant entry and exit rates are correlated across industries. Figure 2 shows the variation in entry and exit rates within and across two SIC (Standard Industrial Classification) digit industries in the US manufacturing sector for 1987-1992. ${ }^{8}$ Entry and exit rates do indeed appear to have a

Samuelson (1988) for evidence on entry and exit from 1963-1987.

${ }^{8}$ Entry and exit rates are calculated separately for each 4-digit industry. Each 
Who Dies? International Trade, Market Structure, and Industrial Restructuring 7

strong industry-specific component. Apparel (SIC 23), lumber (24), furniture (25), printing and publishing (27), and misc manufacturing (39) have above average entry and exit rates in most of their 4-digit subsectors. In contrast, paper (26), chemicals (28), petroleum and coal (29), primary metals (33), and fabricated metals (34) show below average entry and exit rates. Hopenhayn (1992a) constructs a dynamic model of industry evolution that attempts to match these facts. In his model, industry-specific entry costs provide for positive covariation in entry and exit rates. One striking attribute of this class of models is that entry and exit exactly offset one another allowing for no net entry differences across industries.

Also reported, but usually overlooked, in Dunne, Roberts and Samuelson (1988), is the fact that the comovement of entry and exit rates across industries is largely due to persistent industry effects. Controlling for time-invariant industry effects, entry and exit rates move in opposite directions. The variation in net entry rates across four-digit industries is substantial. Figure 3 reports the variation in net entry rates within and across two-digit industries. Again there appear strong industry components as apparel (23), petroleum (29) and leather (31) have negative net entry for almost all 4-digit industries while subsectors in plastics (30) and instruments (38) almost all have positive net entry. Existing models of market structure cannot explain such variation. We employ a simple Heckscher-Ohlin model of endowment-based international trade to understand what is driving the substantial heterogeneity in net entry rates across industries.

\subsection{Heckscher-Ohlin, Entry and Exit}

In this section we consider the implications of a Heckscher-Ohlin trade model on plant entry and exit. For ease of exposition, we will

two digit industry is then represented by a pair of box and whisker plots with entry on the left and exit on the right. The boxes represent the interquartile range of the 4 -digit entry and exit rates, i.e. the 25 th to the 75 th percentile. The line within the box is the rate for the median 4-digit sector within the two digit industry. The whiskers extend to $\pm 1.5^{*}$ the interquartile range. 
Who Dies? International Trade, Market Structure, and Industrial Restructuring 8

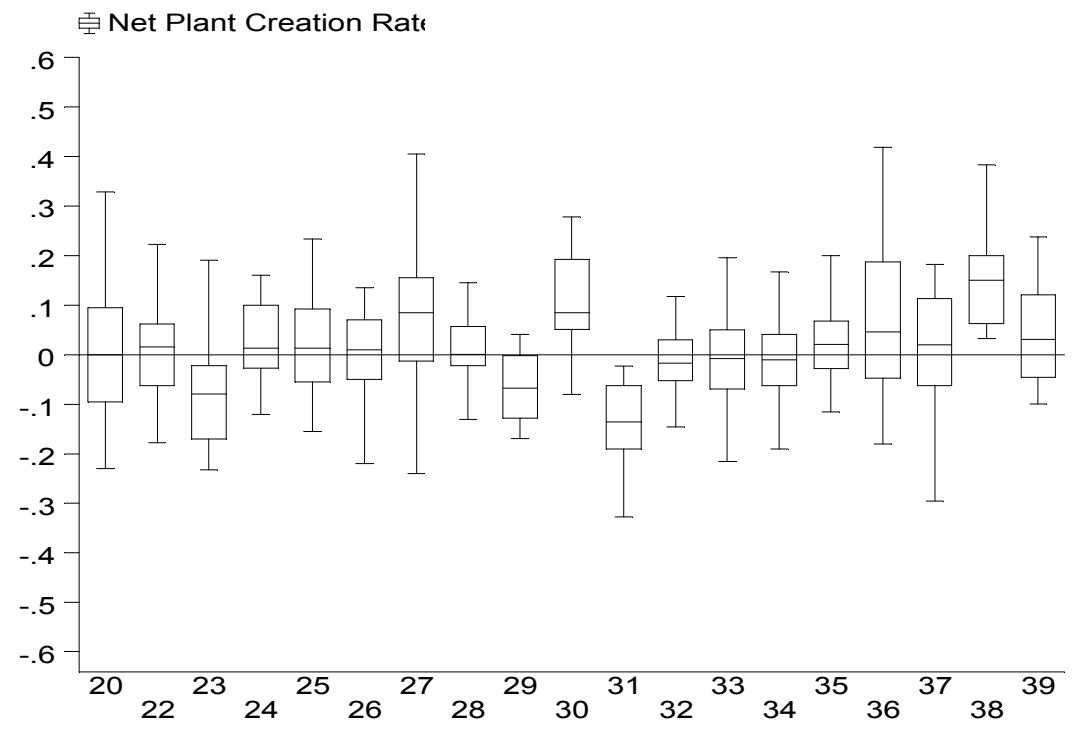

Figure 3: Net Plant Creation Rates, 4-Digit (SIC) Industries, 19871992

start with the simplest version of the H-O model with two factors and two goods. Figure 4 shows the factor accumulation path for a country over time. As the country moves from point 0 to point 1 accumulating skill, the labor intensive industry decreases in size until it finally shuts down.

Even this basic model gives some natural predictions about where we should expect to see plant shutdowns. If the US occupies a single cone and is accumulating skill, then we would expect to see higher exit rates in labor-intensive industries and higher entry rates in skillintensive industries. ${ }^{9}$

\footnotetext{
${ }^{9}$ One problem with the basic $\mathrm{H}-\mathrm{O}$ trade model is that it has no predictions on intra-industry structure. The reduction in output in the labor-intensive industry could come through plant shutdowns or reductions in plant size. Even the complete disappearance of the industry could occur with existing plants chang-
} 
Who Dies? International Trade, Market Structure, and Industrial Restructuring 9

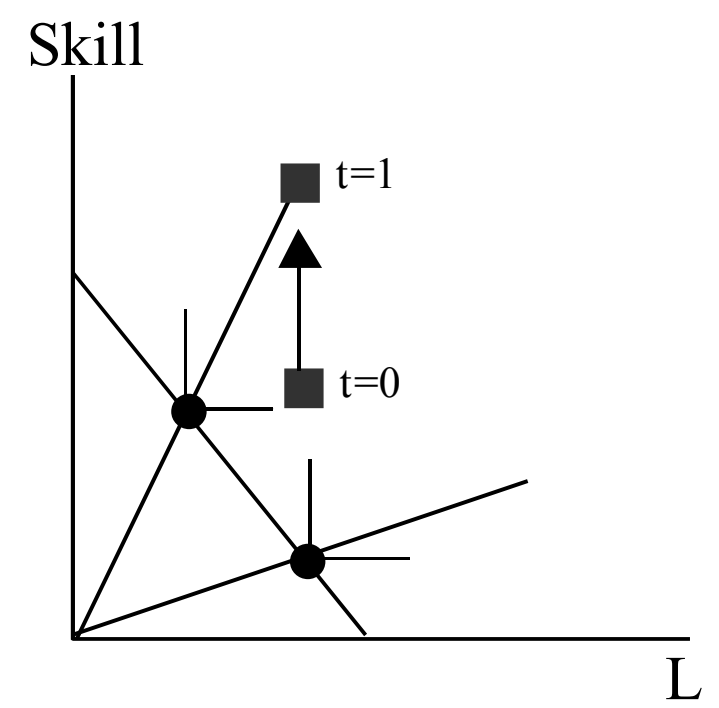

Figure 4: H-O Model: 2 factors, 2 goods, 1 region 
Who Dies? International Trade, Market Structure, and Industrial Restructuring 10

In addition to accumulating skill, the US has been increasing its capital-intensity substantially during the 1970s and 1980s. The sim-

ple $\mathrm{H}-\mathrm{O}$ model predicts that, conditional on skill-intensity, shutdowns would be highest in the least capital-intensive sectors. One problem with looking at industry capital intensity is that it may also be correlated with industry entry costs, i.e. semiconductors versus shoes. As we will discuss below, market structure models, i.e. Hopenhayn (1992a), predict that both entry and exit rates would be lower in capital-intensive industries (semiconductors) and higher in laborintensive industries (shoes). However, while entry and exit rates might both be lower, the $\mathrm{H}-\mathrm{O}$ model predicts that the net entry rate across industries would be positively related to capital intensity, i.e. we would expect to see more net entry in the chip industry than in the footwear business. The steady state market structure models have no predictions about net entry rates as entry and exit are always balanced.

\subsubsection{Regions in the $\mathrm{H}-\mathrm{O}$ model}

One interesting attribute of the $\mathrm{H}-\mathrm{O}$ model is that it yields predictions not only about heterogeneity in industry entry and exit but also about which regions are most likely to experience substantial plant turnover. If the regions of the US have different factor endowments, even if they occupy a single factor price equalization cone, then the $\mathrm{HO}$ model contains additional predictions about the location and factor intensity of plant shutdowns. In Figure 5, region B is accumulating skilled labor while endowments in region $\mathrm{A}$ are unchanged. As a result, both the exit rate and entry rates should be higher in region $B$ than in region $\mathrm{A} .{ }^{10}$ The size of the change in the regional endowment

ing products. Throughout this paper we assume some of the output adjustment margin will occur through net exit. In our empirical work this is a maintained hypothesis.

${ }^{10}$ While the H-O model does not comment on entry and exit in the absence of endowment changes, we would expect both regions to experience positive exit and entry rates even in the steady state for the reasons outlined in the market 
Who Dies? International Trade, Market Structure, and Industrial Restructuring 11

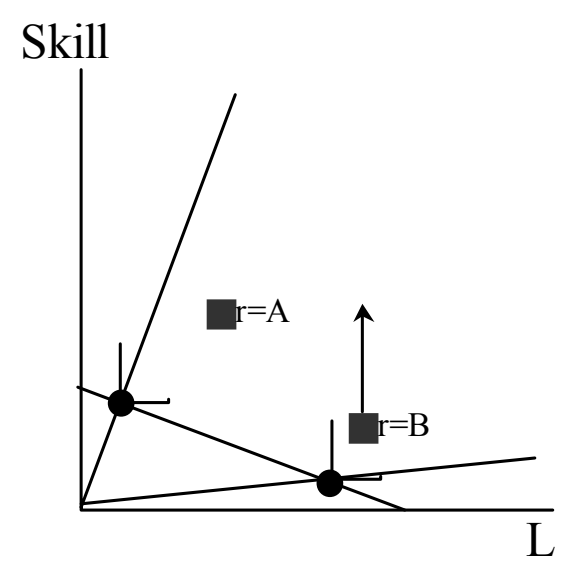

Figure 5: H-O Model: 2 factors, 2 goods, 2 regions

matters for plant closure and birth. Regions with relatively small changes in endowments would see fewer shutdowns and startups. In addition, the exit rates should be higher in the labor intensive industries in region $\mathrm{B}$ than in the same industries in region $\mathrm{A}$ and the entry rates should be higher in the skill intensive industries in region $\mathrm{B}$ than those in region $\mathrm{A}$. The $\mathrm{H}-\mathrm{O}$ model with multiple regions thus predicts that regional exit and entry rates should be correlated with regional endowment changes. Perhaps more importantly, the interaction of increased regional skill (and capital) abundance with industry skill (capital) intensity should be positively correlated with entry rates and negatively correlated with exit rates. ${ }^{11}$ Moreover, both of these effects would remain even if the regions were in different factor price

structure models below.

${ }^{11}$ Note that with identical factor prices across the regions, there is no incentive for factors to migrate. Of course, we must take changes in regional factor endowments as exogenous. 
Who Dies? International Trade, Market Structure, and Industrial Restructuring 12

cones.

The H-O model yields predictions about entry, exit and net entry across regions and industries. In a country that is accumulating capital and skills such as the US, plant closures will occur more frequently in the least capital and skill-intensive industries and plant births will occur more often in the most capital and skill intensive industries. In addition, regions that are changing their endowments rapidly will be more likely to experience plant turnover, both entry and exit. Within regions, industries with factor intensities at odds with the new endowments will be more likely to have high exit rates while industries with similar factor usage most similar to the new endowments will experience higher entry rates.

\subsection{Market Structure Models}

There is a body of research on plant entry and exit stimulated largely by the work of Dunne, Roberts, and Samuelson (1988, 1989), (henceforth DRS). Looking across industries, DRS (1988) find that plant entry and exit rates at the level of the four digit (SIC) industry are strongly positively correlated, and that the correlation persists over time. This can be seen in Figure 6 for the 1987-92 period. Entry rates are plotted against exit rates for 4-digit manufacturing industries and show a strong positive correlation. ${ }^{12}$ However, once they control for persistent industry effects, DRS find that entry and exit rates are negatively correlated. They conclude that there are substantial persistent structural factors that move entry and exit rates in the same direction and industries are more consistently characterized by

${ }^{12}$ The entry rate in the figure is defined as

$$
E R_{i t}=\frac{\text { Birth }_{t \rightarrow t+5}}{\text { All Plants }} \text { Alt5 }
$$

and the exit rate as

$$
X R_{i t}=\frac{\text { Death } s_{t \rightarrow t+5}}{\text { All Plants }} .
$$


Who Dies? International Trade, Market Structure, and Industrial Restructuring 13

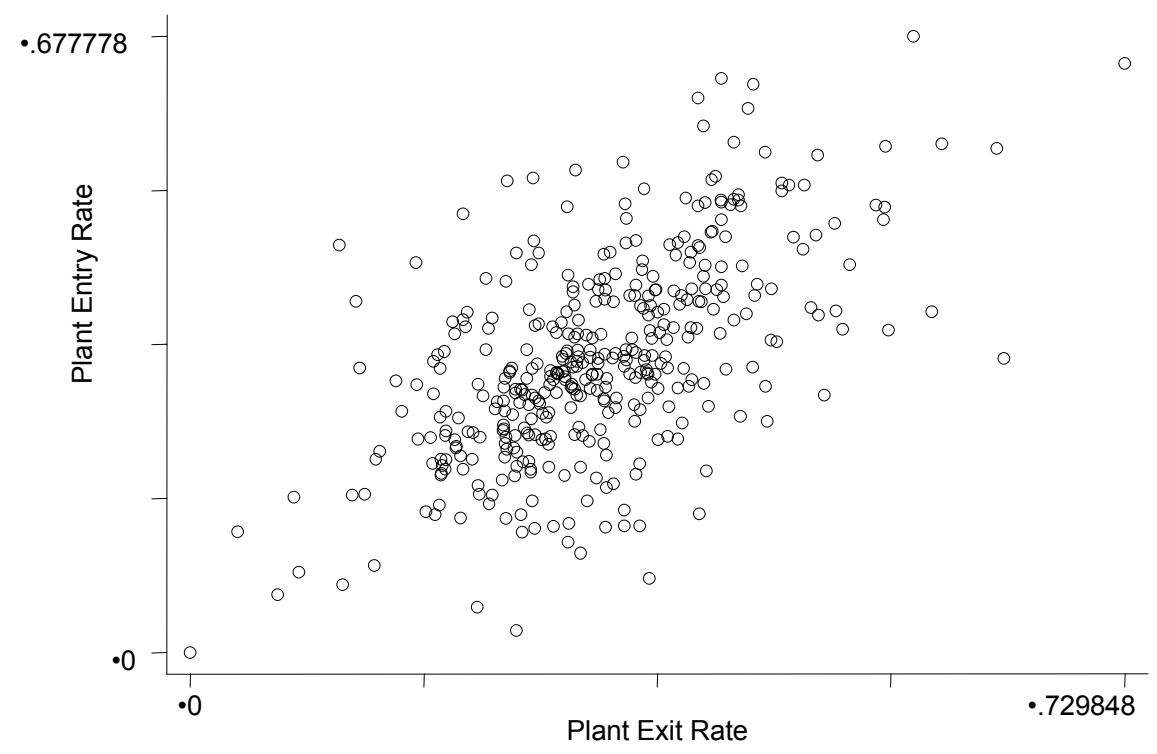

Figure 6: Industry Entry and Exit Rates, 1987-1992

turnover than net entry rates.

These findings and conclusions of DRS had a strong impact on the subsequent theoretical literature generating a variety of market structure models. Hopenhayn (1992a,b) develops a general equilibrium model of entry and exit to largely match the DRS facts. Hopenhayn's model focuses on a steady state with balanced entry and exit. Comparative static exercises reveal that increases in entry costs lower both entry and exit rates causing them to move together.

Surprisingly, there has been little empirical work on the crossindustry determinants of entry and exit rates. Dunne and Roberts (1991) find that industries with lower entry and exit rates are more capital intensive, have higher average firm size, and higher price-cost margins. In our subsequent empirical work, we use these variables and other proxies for the entry costs envisioned by Hopenhayn (1992a) and provide evidence on the source of the positive correlation between in- 
Who Dies? International Trade, Market Structure, and Industrial Restructuring 14

dustry entry and exit rates. In addition, both the theoretical and empirical literatures have ignored the fact that controlling for persistent industry effects entry and exit rates are negatively correlated at the industry level. We attempt to rectify this omission by considering the implications of models of international trade in determining industry entry and exit rates as well as differences in net entry rates across industries.

To develop a complete picture of the variation in entry and exit across industries and regions, we need both variation in net entry and industry comovements in entry and exit rates. By itself, neither the endowment-based trade model nor the market structure model gives a complete picture.

\section{Empirical results}

The predictions from the market structure and trade models presented above are essentially medium to long-run in nature. To test them, we use data from the U.S. Census of Manufactures (CM) conducted every fifth year from 1972 to 1992 and contained in the Longitudinal Research Database of the Bureau of the Census. This data has been described in detail elsewhere and was the source employed by DRS in their studies which covered the period 1963-1987.

Several attributes of the data are especially important for our analysis. First, we characterize a plant exit or death as the case when an establishment is in a Census in year $t$ but not in year $t+5$. If that plant were to reappear in a subsequent Census, either under the same or different management, we would register an entrant or birth. The entry rate for industry $\mathrm{i}$ in year $\mathrm{t}$ is defined $\mathrm{as}^{13}$

$$
E R_{i t}=\frac{\text { Birth }_{t \rightarrow t+5}}{0.5\left(\text { All } \text { Plants }_{t}+\text { All Plant } \text { Pl }_{t+5}\right)}
$$

\footnotetext{
${ }^{13}$ We use these definitions of entry, exit, and net entry rates in all the empirical specifications. These definitions allow us to calculate measures even when no plants are operating in the cell in one of the years.
} 
Who Dies? International Trade, Market Structure, and Industrial Restructuring 15

and the exit rate as

$$
X R_{i t}=\frac{\text { Death }_{t \rightarrow t+5}}{0.5\left(\text { All Plant } s_{t}+\text { All Plant } \text { Pl }_{t+5}\right)}
$$

and the net entry rate as

$$
N R_{i t}=\frac{\text { Birth }_{t \rightarrow t+5}-\text { Death }_{t \rightarrow t+5}}{0.5\left(\text { All Plant }_{t}+\text { All Plant } \text { Pl+5 }_{t+5}\right)} .
$$

For our industry and regional analysis, we employ a variety of measures at the industry level. ${ }^{14}$ These are all calculated in year $t$ for the interval from $t$ to $t+5$. For our measure of industry physical capital intensity, we employ the level of log capital per worker for the median plant in the industry. Similarly for skill intensity, we use the level for the median plant in the industry of the share of nonproduction wages in total wages. ${ }^{15}$

One main problem in attempting to test the predictions of the market structure models is the lack of data on the sunk entry costs which drive the comovements of industry exit and entry rates. Hopenhayn (1992a) points out that changes in sunk entry costs have a potentially ambiguous impact on firm size and that profits and market share will be higher for large firms but not necessarily for small firms. We employ measures of total employment, markups and concentration of output at the industry level in an attempt to proxy for factors that may act as barriers to entry. Our measure of plant size is the log total employment at the median plant in the industry. Markups are defined as shipments less variable costs divided by shipments, and the industry

\footnotetext{
${ }^{14}$ Throughout the paper, industry refers to a 4-digit Standard Industrial Classification. We have dropped all industries with a code ending in the number 9 , as these typically group heterogeneous products not elsewhere classified. In addition, we drop SIC 21 due to the small number of firms. We are left with 387 out of 449 industries.

${ }^{15} \mathrm{~A}$ substantial number of very small plants do not receive a long form Census questionnaire. We exclude these plants when we calculate our median industry measures. They are included in the calculation of the industry and regional entry and exit rates.
} 
Who Dies? International Trade, Market Structure, and Industrial Restructuring 16

measure is again the value for the median plant. For our concentration measure, we construct a Herfindahl index based on total shipments.

Turning our attention to the endowment data, we construct proxies for both physical and human capital intensity. Our measure of capital intensity is log capital per worker. ${ }^{16}$ The only distinction of labor varieties in the data are non-production and production workers. Ideally, we would like to have a better measure of skilled or educated workers at the plant but the limitations of the Census preclude a finer measure. The main problem with the non-production worker share is that it includes both high-education (engineers) and low-education (janitors) workers. To obviate this problem as much as possible, in all our empirical work, we use the wage share of non-production workers instead of their employment share.

Perhaps the most interesting prediction from the Heckscher-Ohlin model has to do with the interaction of changing regional endowment and initial industry factor intensity. Since we are interested in regions that correspond to factor markets, we use the definition of a Labor Market Area (LMA) given by the Commerce Department rather than US states or the coarser Census regions. LMAs can cross state boundaries, as in the New York, NY LMA which includes parts of New Jersey and Connecticut, or be contained within states, as in the San Francisco-Oakland-San Jose LMA which covers only part of northern California. These regions are based on county groups with common commuting patterns recorded in the 1970 and 1980 population censuses. According to these definitions, there are 183 LMAs in the US of which we use $181 .^{17}$

\footnotetext{
${ }^{16}$ Results from higher dimension trade theory suggest we should employ inputoutput ratios as our measure of factor intensity for the industry or plant, i.e. $\frac{K}{Q}$ where $Q$ is value-added, rather than the capital-labor ratio, $\frac{K}{L}$. However, across industries and plants factor intensities vary inversely with multi-factor productivity levels and thus do not allow us to separately identify the role of factor usage and productivity. We therefore choose to use the log capital-labor ratio and non-production wage share in our empirical specifcations.

${ }^{17}$ Over time commuting distances have lengthened and increasingly distant counties have become part of the same labor market. As a result of the 1990 census,
} 
Who Dies? International Trade, Market Structure, and Industrial Restructuring 17

The trade model points to the importance of changes in factor endowments of the regions and the interaction of those changes with initial industry factor usage. In constructing measures of regional factor endowments, we face two problems. First, we only observe factors employed in manufacturing, a problem we cannot solve given the data. Second, individual plant shutdowns might affect regional endowment measures. To avoid problems with endogeneity, when we construct regional measures of relative factor endowments, we exclude factor usage within the same two digit SIC. ${ }^{18}$ The variables of interest are the changes in log capital-labor ratio and non-production wage share for the LMA and the interactions of those changes with the industry levels in the initial year.

\subsection{Empirical Results (Industry)}

For the industry level results, we estimate tobit specifications with standard errors adjusted for potential heteroskedasticity within industries of the form

$$
\begin{aligned}
& E R_{i t}=c+\beta I C_{i t}+d_{t}+e_{i t} \\
& X R_{i t}=c+\gamma I C_{i t}+d_{t}+\nu_{i t} \\
& N R_{i t}=c+\delta I C_{i t}+d_{t}+\nu_{i t}
\end{aligned}
$$

where $c$ is a constant, $d_{t}$ is a set of year dummies to control for aggregate factors such as business cycles, and $I C_{i t}$ is vector of industry characteristics. ${ }^{19}$

For industry entry rates, the $\mathrm{H}-\mathrm{O}$ model predicts a positive coefficient on the non-production wage share, our proxy for human capital

the number of labor market areas has been reduced to 172. Given the time span of our data, we chose to work with the larger number of regions based on the earlier censuses. We exclude Hawaii and Alaska from the analysis.

${ }^{18} \mathrm{In}$ other words, for a plant in two-digit industry $\mathrm{Y}$ in region 1 , the change in the regional $\mathrm{K} / \mathrm{L}$ ratio is the change in the $\mathrm{K} / \mathrm{L}$ ratio for all plants outside of industry $\mathrm{Y}$ in region 1.

${ }^{19}$ The tobits are necessary because some industries have truncated exit and entry rates. 
Who Dies? International Trade, Market Structure, and Industrial Restructuring 18

intensity. For physical capital the sign of the coefficient is ambiguous. Given the increase in capital intensity in the US during the period, the $\mathrm{H}-\mathrm{O}$ model predicts a positive correlation between physical capital and entry rates. However, if physical capital intensity acts a barrier to entry, then we would expect a negative correlation. Similarly, we expect negative coefficients on each of the market structure variables: size, markup and concentration.

Expected coefficients in the industry exit rate regressions should be negative for all the variables. According to the endowment trade model, exit rates should be lower for industries intensive in both physical and human capital as the US is becoming more capital and skill intensive. Higher entry costs (size, markup, concentration, capital intensity) should also reduce exit rates.

Table 1 reports the univariate tobits for each of the industry characteristics for both entry rates and exit rates. The non-production wage share has the correct sign in both cases, with a significant positive coefficient for industry entry rates and a negative, although insignificant, coefficient in the exit specification. High skill industries have higher entry and lower exit rates. The capital-labor ratio has the expected negative and significant relationship with exit as predicted by both the market structure and H-O trade models. Higher industry capital intensity is significantly negatively associated with entry rates suggesting that the market structure effects dominate. The size and markup measures have the expected sign in both the entry and exit rate specifications, although only the markup measure is not statistically significant for entry rates. The positive coefficient on the industry Herfindahl index for entry rates is at odds with the prediction of the market structure models.

We report the results including all the measures in a single regression in Table 2. Again, with the exception of the concentration measure, all the variables have the predicted signs and are significant at the 1 percent level. ${ }^{20}$ Skill intensity is correlated with higher entry

\footnotetext{
${ }^{20}$ The non-production wage share is significant only at the $10 \%$ level in the exit specification.
} 
Who Dies? International Trade, Market Structure, and Industrial Restructuring 19

rates and lower exit rates as suggested by the H-O trade model with human capital accumulation. As predicted by the market structure models, both entry and exit rates are lower in industries with larger plants, higher markups and greater capital intensity.

One important distinction between the market structure and $\mathrm{H}$ $\mathrm{O}$ trade models is the implication for net entry rates. The market structure models by construction have no net entry in steady state. This suggests that measures such as size and markup should have no relation to net entry rates. The $\mathrm{H}-\mathrm{O}$ trade model, on the other hand, focuses precisely on the changing composition of output in response to factor accumulation. This model predicts that net entry rates should be positively correlated with both physical and human capital intensity.

Tables 3 and 4 report the results for industry net entry rates for both the univariate and multivariate specifications. As predicted, both physical and human capital intensity are positively correlated with net entry rates at the industry level. The market structure measures of plant size and markups are not significantly correlated with net entry in either specification suggesting that they may indeed be proxying for persistent industry characteristics that affect both entry and exit rates proportionately. The concentration measure does not conform to the predictions of the model as it has a positive and significant correlation with net entry.

\subsection{Empirical Results (Region-Industry)}

We turn now to the region-industry predictions of the $\mathrm{H}-\mathrm{O}$ trade model. As described above, we have 181 regions and 387 industries in our data. Of course not every region contains a full range of industries; on average only 47 percent of the region-industry cells have active plants. There is a large amount of industry mixing both within and across regions. As with the four-digit industries, entry and exit rates are positively correlated across region-industry cells as shown in 
Who Dies? International Trade, Market Structure, and Industrial Restructuring 20

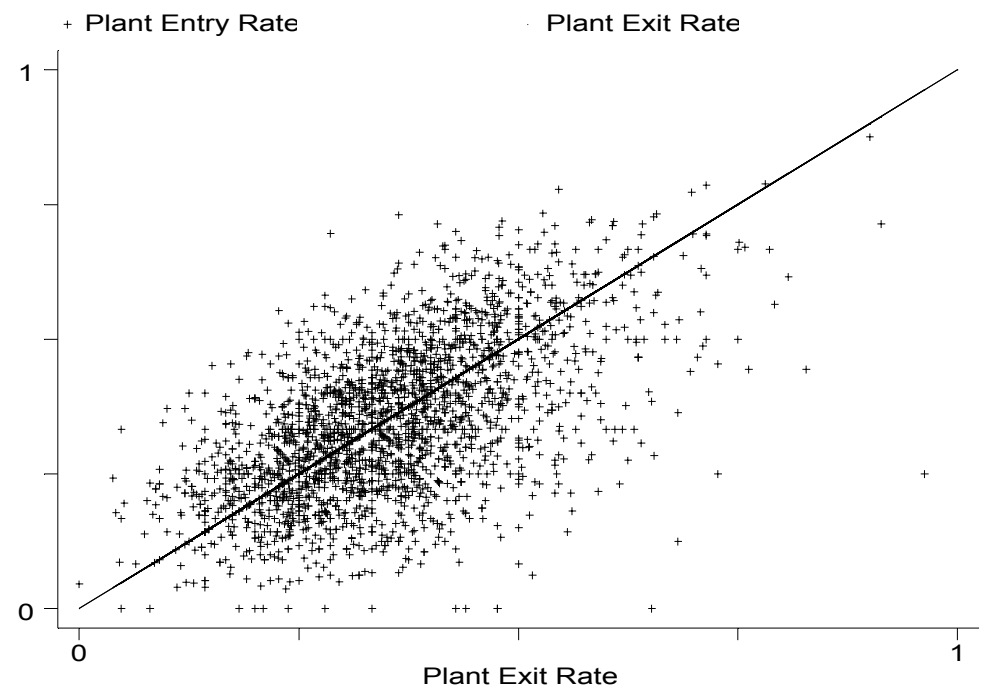

Figure 7: Region-Industry Entry and Exit Rates, 1987-1992

Figure $7 .^{21}$ However, only 30 percent of the variation in entry rates can be explained by exit rates. In any given five year interval, 15 industries completely shut down and 20 new industries start up in the average region. In this section, we consider two related components of regional entry and exit. First, we consider exactly which regionindustry pairs are the most likely to experience entry, then we consider magnitude of the entry, exit, and net entry rates in light of the two types of models.

To understand where entry is occurring we estimate probits of the form

$$
\begin{aligned}
& \operatorname{Pr}\left(E R_{\text {irt }}>0\right)=f\left(c+I C_{i t}+d_{t}\right)+e_{i t} \\
& \operatorname{Pr}\left(E R_{\text {irt }}>0\right)=f\left(c+\delta \Delta R E_{r t}+d_{t}\right)+e_{i t} \\
& \operatorname{Pr}\left(E R_{\text {irt }}>0\right)=f\left(c+I C_{i t}+\delta \Delta R E_{r t}+\gamma\left(\Delta R E_{r t} \cdot I C_{i t}\right)+d_{t}\right)+e_{i t}
\end{aligned}
$$

\footnotetext{
${ }^{21}$ Only region-industries cells with more than 20 plants and more than 10 firms are shown.
} 
Who Dies? International Trade, Market Structure, and Industrial Restructuring 21

where $I C_{i t}$ is a vector of industry characteristics, $\Delta R E_{r t}$ is a vector of changes in regional endowments (human and physical capital) and $\Delta R E_{r t} \cdot I C_{i t}$ is a vector of interactions between regional endowment changes and industry factor intensities.

We expect the probability of entry in a region-industry cell to be increasing in industry capital intensities ( $\mathrm{H}-\mathrm{O}$ trade model), both human and physical, and decreasing in the sunk cost of entry for the industry proxied by plant size, markup, and concentration (market structure model). As before the sign on industry log capital labor ratio is ambiguous as it encompasses elements from both models. The $\mathrm{H}-\mathrm{O}$ trade model predicts that regions with larger increases in human and physical capital will have higher entry (and exit) rates. For a given region, entry will occur most often in industries with compatible factor needs, i.e. regions with rapidly increasing physical and human capital will see a higher probability of entry in high capital industries. The expected signs on the interaction terms are positive.

Table 5 contains the results from the univariate and multivariate specifications. As expected, high industry non-production wage shares are associated with a higher probability of entry. The measure of industry capital intensity has a negative and significant coefficient suggesting, as in the industry results above, that capital intensity is associated with high entry costs. Both the regional endowment measures are positive and significant at the 1 percent level. Regions with increasing human and physical capital stocks are more likely to see entry. Finally, among the proxies for entry costs, the size and concentration measures have the expected sign. Industries with high markups, however, have higher, not lower probability of entry.

The last specification in Table 5 contains all the variables including the interaction terms. Both the interaction terms have positive signs and are significant at the 1 percent level exactly as predicted by the $\mathrm{H}-\mathrm{O}$ trade model with multiple regions. Indeed, all the variables have the expected signs and most are significant at the 1 percent level. ${ }^{22}$

\footnotetext{
${ }^{22}$ The coefficients on the regional endowment changes are now negative. While we expect the unconditional coefficients to be positive, once we have added inter-
} 
Who Dies? International Trade, Market Structure, and Industrial Restructuring 22

In Table 6, we report results for entry and exit rates for the regionindustry cells. We calculate entry and exit rates as in Equations 1 to 3 . As mentioned above, there are large numbers of regions with industries shutting down and starting up in every five year period. As a result, our dependent variables will be censored on both ends. We employ univariate and multivariate tobit estimators for entry and exit rates of the form

$$
\begin{aligned}
& R_{i r t}=f\left(c+I C_{i t}+d_{t}\right)+e_{i t} \\
& R_{i r t}=f\left(c+\delta \Delta R E_{r t}+d_{t}\right)+e_{i t} \\
& R_{i r t}=f\left(c+I C_{i t}+\delta \Delta R E_{r t}+\gamma\left(\Delta R E_{r t} \cdot I C_{i t}\right)+d_{t}\right)+e_{i t}
\end{aligned}
$$

with the variables defined as above. ${ }^{23}$

Both sets of estimates again largely conform to our priors from the two models. In the univariate specifications, larger regional endowment changes are positively associated with both exit and entry rates as predicted by the $\mathrm{H}-\mathrm{O}$ trade model. Higher skill shares have positive and significant coefficients for both entry and exit, the former is predicted by the model while the higher exit rate is not consistent with the $\mathrm{H}-\mathrm{O}$ predictions. Industry capital intensity, median plant size and concentration ratios are negatively correlated with both entry and exit as in the industry regressions. ${ }^{24}$

In the multivariate specification, we find that again the industry variables enter with the predicted signs and are usually significant at the 1 percent level. Of particular interest are the interactions between changes in regional endowments and industry factor intensities. For both capital intensity and non-production wage share the interaction terms have the expected signs and are all significant at least at the 5 percent level. Regions increasing human and physical capital gain industries that are relatively human and physical capital intensive at faster rates and lose labor intensive industries. Even within the

action terms we have no prior on the expected signs.

${ }^{23}$ The tobit estimator relies heavily on the assumption of normality for consistency of the estimates.

${ }^{24}$ The markup measure has the wrong sign and is significant for entry rates. 
Who Dies? International Trade, Market Structure, and Industrial Restructuring 23

US, we see clear evidence that regional factor endowments affect the location and type of industries in the manner predicted by endowmentbased trade theory. These findings are confirmed in Table 7 where we run tobits for net entry rates. Regions acquiring human and physical capital have significantly higher net entry in capital-intensive industries as predicted by the $\mathrm{H}-\mathrm{O}$ model.

In this section, we have explored plant exit and entry across industries and regions. We confirm the well-known stylized fact that entry rates and exit rates are positively correlated across industries. Using the predictions of market structure models, we confirm that proxies for entry cost are negatively correlated with both entry and exit rates across industries. We show that net entry rates are substantial and have significant variation across industries and regions.

To explain this industry heterogeneity in net entry, we turn to a simple Heckscher-Ohlin model of trade. In a country that is accumulating both physical and human capital such as the US, the $\mathrm{H}-\mathrm{O}$ model predicts that industry capital intensity should be positively correlated with net entry. We confirm this in the data and show that most of the entry cost measures are uncorrelated with net entry, again as predicted by the market structure models.

Finally, we consider regional variation in industry entry and exit rates. While the market structure models are silent on where industries should locate, the $\mathrm{H}-\mathrm{O}$ trade model predicts that increases in regional capital intensity should be correlated with higher exit and entry rates. We find significant evidence for this correlation. In addition, the $\mathrm{H}-\mathrm{O}$ model predicts that entry in capital-deepening regions should be in capital intensive industries and exit in labor intensive industries. Once again we find support for this hypothesis.

This work at the industry and regional levels confirms the importance of the market structure models in explaining industry level comovements in plant entry and exit rates. More importantly, we introduce endowment-based trade theory as an important additional component of the ongoing evolution of the US manufacturing sector. While the market structure models had little role for net entry, a sim- 
Who Dies? International Trade, Market Structure, and Industrial Restructuring 24

ple $\mathrm{H}-\mathrm{O}$ trade model does well in not only predicting which industries should see net entry but also where those capital-intensive industries will locate.

\section{Conclusions}

In this paper, we look at the restructuring of US manufacturing. While previous work has focused on the positive correlation of plant failures and births across industries, we concentrate on the variation in net entry across both industries and regions. We document the large degree of heterogeneity in net entry and develop testable predictions from a simple endowment-based trade model.

Using the population of US manufacturing plants from 1972-1992, we find strong support for the predictions of the Heckscher-Ohlin trade model at the industry and regional level. The H-O trade model correctly predicts that capital and skill intensive industries should have higher net entry rates than labor intensive industries in a country that is accumulating skill and capital. The $\mathrm{H}-\mathrm{O}$ model also contains implications for regional variation in entry, exit, and net entry. Regions with rapidly changing endowments are correctly predicted to have both higher entry and exit rates. In addition, the interactions of regional endowment accumulation and industry factor intensity are positively correlated with net entry rates. Regions accumulating capital have higher net entry in capital intensive industries. This means a low-skill, labor-intensive plant in a region that is rapidly deepening its capital stock is more likely to close than a high-skill, capital intensive plant in the same region.

These results provide the first attempt to provide an explanation for the substantial heterogeneity in net entry rates across industries in the US manufacturing sector. A simple Heckscher-Ohlin trade model does a good job of identifying the characteristics of industries and regions associated with plant closure. Much work remains to be done. The implications of endowment-based trade theory for dynamic industry models have yet to be explored. In addition, future research 
Who Dies? International Trade, Market Structure, and Industrial Restructuring 25

should consider more carefully the effects of macroeconomic variables such as exchange rate movements as well as the link between these results on plant closure to issues of factor prices, especially wage levels and inequality. 
Who Dies? International Trade, Market Structure, and Industrial Restructuring 26

\section{References}

Dunne, Timothy, and Mark J. Roberts, (1991) "Variation in Producer Turnover Across US Manufacturing Industries," in Entry and Market Contestability: An International Comparison, P.A. Geroski and J Schwalbach, Ed.s, Basil Blackwell.

Dunne, Timothy, Mark J. Roberts, and Larry Samuelson, (1988) "Patterns of firm entry and exit in US manufacturing industries", Rand Journal of Economics, Vol. 19(4), 495-515.

Dunne, Timothy, Mark J. Roberts, and Larry Samuelson, (1989) "The Growth and Failure of US Manufacturing Plants", Quarterly Journal of Economics, Vol. 104(4), 671-698.

Hanson, Gordon H., and Matthew J. Slaughter, (1999) "The Rybczynski Theorem, Factor-Price Equalization, and Immigration: Evidence from US States." NBER Working Paper \#7074.

Harrigan, James and Egon Zakrajsek, (2000) "Factor Supplies and Specialization in the World Economy." Federal Reserve Bank of New York mimeo.

Hopenhayn, Hugo, (1992a) "Entry, Exit, and Firm Dynamics in Long Run Equilibrium." Econometrica, 60(5), 1127-1150.

Hopenhayn, Hugo, (1992b) "Exit, Selection and The Value of Firms." Journal of Economic Dynamics and Control, 16, 621-653.

Schott, Peter K., (1999), "One Size Fits All? Specialization, Trade, and Income Inequality." Yale School of Management Working Paper. 
Table 1: Industry Entry and Exit Rates, 1972-1992

$\begin{array}{lrrrrrr} & \text { Entry } & & & & \text { Exit } \\ \text { Spec. } \underline{\text { RHS Variable }} & \underline{\text { Coef. }} & \underline{\text { S.E. }} & \underline{\text { p-value }} & \underline{\text { Coef. }} & \underline{\text { S.E. }} & \text { p-value } \\ \text { 1. Log capital-labor ratio } & -0.037 & 0.004 & 0.00 & -0.054 & 0.003 & 0.00 \\ \text { 2. Non-production wage share } & 0.276 & 0.032 & 0.00 & -0.010 & 0.025 & 0.67 \\ \text { 3. Log total employment } & -0.036 & 0.004 & 0.00 & -0.044 & 0.003 & 0.00 \\ \text { 4. Markup } & -0.036 & 0.026 & 0.18 & -0.118 & 0.020 & 0.00 \\ \text { 5. Industry Herfindahl index } & 0.253 & 0.069 & 0.00 & -0.101 & 0.053 & 0.06\end{array}$

Table 2: Industry Entry and Exit Rates, 1972-1992

Entry

Spec. RHS Variables

1. Log capital-labor ratio

Non-production wage share

Log total employment

Markup

Industry Herfindahl index

Coef

$$
-0.032 \quad 0.004 \quad 0.00
$$

$0.253 \quad 0.032$

0.00

$-0.039$

Exit

$\begin{array}{lll}-0.024 & 0.005 & 0.00\end{array}$

$-0.03$

$-0.069$

0.025

0.01

$-0.11$

Coef. $\quad$ S.E. $\begin{array}{lll}-0.045 & 0.003 & 0.00\end{array}$

$$
0.334 \quad 0.066 \quad 0.00
$$

0.01
0.023

0.023

0.08

$\begin{array}{ll}0.003 & 0.00\end{array}$

$\begin{array}{ll}0.018 & 0.00\end{array}$

0.047

0.77 
Table 3: Industry Net Entry Rates, 1972-1992

Spec. RHS Variable

1. Log capital-labor ratio

2. Non-production wage share

3. Log total employment

4. Markup

5. Industry Herfindahl index
Net Entry

Coef. $\quad \underline{\text { S.E. p-value }}$

$\begin{array}{lll}0.017 & 0.007 & 0.01\end{array}$

$\begin{array}{lll}0.285 & 0.055 & 0.00\end{array}$

$\begin{array}{lll}0.007 & 0.008 & 0.35\end{array}$

$\begin{array}{lll}0.083 & 0.055 & 0.13\end{array}$

$\begin{array}{lll}0.359 & 0.117 & 0.00\end{array}$

Table 4: Industry Net Entry Rates, 1972-1992

Net Entry

Spec. $\underline{\text { RHS Variables }}$

Coef. $\quad \underline{\text { S.E. p-value }}$

1. Log capital-labor ratio

$\begin{array}{lll}0.126 & 0.007 & 0.05\end{array}$

Non-production wage share

$\begin{array}{lll}0.291 & 0.065 & 0.00\end{array}$

Log total employment

$\begin{array}{lll}0.011 & 0.010 & 0.26\end{array}$

Markup

$\begin{array}{lll}0.050 & 0.047 & 0.29\end{array}$

Industry Herfindahl index

$0.325 \quad 0.120$

0.01 


\section{Table 5: Region-Industry Entry Probits, 1972-1992}

Entry

Spec. RHS Variable

1. Log capital-labor ratio

Coef. S.E. p-value

$\begin{array}{lll}-0.052 & 0.001 & 0.00\end{array}$

2. Non-production wage share

$\begin{array}{lll}0.381 & 0.011 \quad 0.00\end{array}$

4. Change in regional $\log \mathrm{K} / \mathrm{L}$ ratio

$\begin{array}{lll}0.007 & 0.001 \quad 0.00\end{array}$

5. Change in regional non-production wage share

$\begin{array}{lll}0.043 & 0.008 & 0.00\end{array}$

6. Log total employment

$\begin{array}{lll}-0.156 & 0.002 & 0.00\end{array}$

7. Markup

$\begin{array}{lll}0.080 & 0.008 \quad 0.00\end{array}$

8. Industry Herfindahl index

$-2.342$

$0.063 \quad 0.00$

Spec. RHS Variables

Coef. $\quad \underline{\text { S.E. p-value }}$

9. Log capital-labor ratio

$\begin{array}{lll}-0.028 & 0.001 & 0.00\end{array}$

Non-production wage share

$\begin{array}{lll}0.191 & 0.012 & 0.00\end{array}$

Change in regional $\log \mathrm{K} / \mathrm{L}$ ratio

$\begin{array}{lll}-0.020 & 0.004 & 0.00\end{array}$

Change in regional non-production wage share

$-0.042$

$0.026 \quad 0.11$

Interaction- regional change and industry level

Log capital-labor ratio

$\begin{array}{lll}0.011 & 0.001 & 0.00\end{array}$

Non-production wage share

$\begin{array}{lll}0.213 & 0.069 & 0.00\end{array}$

Log total employment

$\begin{array}{lll}-0.123 & 0.002 & 0.00\end{array}$

Markup

$\begin{array}{lll}-0.049 & 0.009 & 0.00\end{array}$

Industry Herfindahl index

$\begin{array}{lll}-1.731 & 0.051 & 0.00\end{array}$




\section{Table 6: Region-Industry Entry and Exit Tobits, 1972-1992}

Spec. RHS Variable

1. Log capital-labor ratio

2. Non-production wage share

4. Change in regional $\log \mathrm{K} / \mathrm{L}$ ratio

5. Change in regional non-production wage share

6. Log total employment

7. Markup

8. Industry Herfindahl index

Spec. RHS Variables

9. Log capital-labor ratio

Non-production wage share

Change in regional $\log \mathrm{K} / \mathrm{L}$ ratio

Change in regional non-production wage share

Interaction- regional change and industry level

Log capital-labor ratio

Non-production wage share

Log total employment

Markup

Industry Herfindahl index
Entry

Coef. $\quad \underline{\text { S.E. }}$ p-value

$\begin{array}{lll}-0.215 & 0.004 & 0.00\end{array}$

$\begin{array}{lll}1.435 & 0.031 & 0.00\end{array}$

$\begin{array}{lll}0.024 & 0.008 & 0.00\end{array}$

$\begin{array}{lll}0.174 & 0.046 & 0.00\end{array}$

$\begin{array}{lll}-0.542 & 0.005 & 0.00\end{array}$

$\begin{array}{lll}0.267 & 0.027 & 0.00\end{array}$

$\begin{array}{lll}-7.589 & 0.098 & 0.00\end{array}$

Coef. $\quad \underline{\text { S.E. }} \underline{\text { p-value }}$

$\begin{array}{lll}-0.134 & 0.004 & 0.00\end{array}$

$\begin{array}{lll}0.827 & 0.034 & 0.00\end{array}$

$-0.129$

0.024

0.00

$-0.177$

0.141

0.21

$\begin{array}{lll}0.060 & 0.008 & 0.00\end{array}$

0.862

0.367

0.02

$\begin{array}{lll}-0.416 & 0.005 & 0.00\end{array}$

$-0.216$

0.028

0.00

$-5.149$

0.00

Coef.

S.E. p-value $\begin{array}{lll}-0.091 & 0.004 & 0.00\end{array}$

$\begin{array}{lll}0.041 & 0.028 & 0.14\end{array}$

$\begin{array}{lll}0.162 & 0.026 & 0.00\end{array}$

$\begin{array}{lll}0.319 & 0.145 & 0.03\end{array}$

$\begin{array}{lrr}\text { Coef. } & \underline{\text { S.E. }} & \text { p-value } \\ -0.118 & 0.004 & 0.00\end{array}$

$\begin{array}{lll}0.105 & 0.025 & 0.00\end{array}$

$\begin{array}{lll}0.001 & 0.008 & 0.86\end{array}$

$\begin{array}{lll}0.004 & 0.460 & 0.92\end{array}$

$\begin{array}{lll}-0.162 & 0.004 & 0.00\end{array}$

$\begin{array}{lll}-0.206 & 0.023 & 0.00\end{array}$

$\begin{array}{lll}-1.504 & 0.083 & 0.00\end{array}$ 
Table 7: Region- Industry Net Entry Tobits, 1972-1992

Net Entry

Spec.

1. Log capital-labor ratio

Coef. $\quad \underline{\text { S.E. }} \quad \underline{\text { p-value }}$

$\begin{array}{lll}-0.005 & 0.004 & 0.18\end{array}$

2. Non-production wage share $\quad 0.249 \quad 0.025 \quad 0.00$

4. Change in regional $\log \mathrm{K} / \mathrm{L} \quad-0.031 \quad 0.008 \quad 0.00$

5. Change in regional non-pror $\quad 0.046 \quad 0.045 \quad 0.31$

$\begin{array}{llll}\text { 6. Log total employment } & 0.016 & 0.004 & 0.00\end{array}$

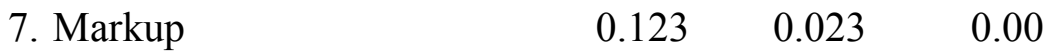

8. Industry Herfindahl index $\quad 1.063 \quad 0.075 \quad 0.00$

Net Entry

Spec. $\underline{\text { RHS Variables }}$

9. Log capital-labor ratio

Coef. $\quad \underline{\text { S.E. }} \quad \underline{\text { p-value }}$

$\begin{array}{lll}-0.015 & 0.004 & 0.00\end{array}$

$\begin{array}{llll}\text { Non-production wage share } & 0.224 & 0.028 & 0.00\end{array}$

Change in regional $\log \mathrm{K} / \mathrm{L} \quad-0.269 \quad 0.026 \quad 0.00$

Change in regional non-pror $\begin{array}{llll}-0.414 & 0.142 & 0.00\end{array}$

Interaction- regional change and industry level

$\begin{array}{llll}\text { Log capital-labor ratio } & 0.080 & 0.008 & 0.00 \\ \text { Non-production wage share } & 1.260 & 0.359 & 0.00 \\ & & & \\ \text { Log total employment } & 0.020 & 0.004 & 0.00 \\ \text { Markup } & 0.115 & 0.024 & 0.00 \\ \text { Industry Herfindahl index } & 1.003 & 0.077 & 0.00\end{array}$

